\title{
A. A. КомAPOBA
}

\section{Сравнительный анализ уровня сформированности информационного мировоззрения студентов педагогического вуза различных направлений} подготовки

Результатом интеграции информатики в гуманитарное и естественно-научное образование является наличие у студентов новых качеств личности, одним из которых является информационное мировоззрение. Включение в учебные планы дисциплин, отвечающих за информационную подготовку студентов, способствует повышению уровня сформированности их информационной компетентности, однако возникает вопрос, является ли это достаточным для формирования информационного мировоззрения. Целью статьи является определение уровня сформированности информационного мировоззрения студентов педагогических вузов трех направлений образования (гуманитарного, естественно-научного, информационно-технического) и его сравнительный анализ.

Для сбора результатов использовалась авторская анкета, состоящая из 40 вопросов и позволяющая оценить уровень сформированности информационного мировоззрения. Для установления достоверности сходства уровня информационного мировоззрения между направлениями рассчитано эмпирическое значение критерия Крускала-Уоллиса.

Проведен сравнительный анализ информационного мировоззрения студентов трех направлений образования (гуманитарного, естественно-научного и информационно-технического). Сделан акцент на сходство и различие во взглядах студентов по выделенным разделам анкетирования. Проведена диагностика уровня сформированности информационного мировоззрения студентов каждого направления, большинство студентов отнесены к группе со средним уровнем. Рассчитанное эмпирическое значение критерия Крускала-Уоллиса $(0,78)$ свидетельствует о примерно одинаковом уровне изучаемого качества личности.

Установлено, что уровень информационного мировоззрения не зависит от количества дисциплин, отвечающих за информационную подготовку. В целом подавляющее большинство студентов всех трех направлений образования имеют средний (85\%), часть студентов низкий (13\%) и лишь $2 \%$ высокий уровень сформированности информационного мировоззрения.

Ключевые слова: информационное мировоззрение, уровень сформированности информационного мировоззрения, гуманитарное направление образования, естественно-научное направление образования, информационно-техническое направление образования

\section{Ссылка для цитирования:}

Комарова А. А. Сравнительный анализ уровня сформированности информационного мировоззрения студентов педагогического вуза различных направлений подготовки // Перспективы науки и образования. 2019. № 3 (39). С. 142-160. doi: 10.32744/pse.2019.3.11 


\section{A. A. Komarova}

\section{Comparative analysis of the level of formation of the informational worldview of students of the pedagogical university of various fields of education}

The result of the integration of computer science into the humanities and science education is the presence of new personality traits in students, one of which is the informational worldview. Inclusion in the curricula of disciplines responsible for the information training of students contributes to the hanging level of formation of their information competence, but the question arises whether this is sufficient for the formation of the informational worldview. The purpose of the article is to determine the level of formation of the informational worldview of students of pedagogical universities of three fields of education (humanitarian, natural-science, informational and technical) and its comparative analysis.

To collect the results, the author's questionnaire was used, consisting of 40 questions and allowing to assess the level of formation of the informational worldview. To establish the reliability of the similarity of the informational worldview between the fields, the empirical value of the Kruskal Wallis criterion is calculated.

Provides a comparative analysis of the informational worldview of students of three fields of education (humanitarian, natural-science, informational and technical). Emphasis is placed on the similarities and differences in the views of students in selected sections of the survey. The diagnostics of the level of formation of the informational worldview of students in each direction was carried out, the majority of students are assigned to the group with an average level. The calculated empirical value of the Kruskal - Wallis criterion (0.78) indicates a roughly similar level of personality trait being studied.

It is established that the level of informational worldview does not depend on the number of disciplines responsible for information training. In general, the overwhelming majority of students in all three fields of education have an average ( $85 \%$ ), some students have low (13\%) and only $2 \%$ have a high level of informational worldview.

Key words: informational worldview, level of formation of informational worldview, humanitarian field of education, natural-science field of education, informational field of education

\section{For Reference:}

Komarova, A. A. (2019). Comparative analysis of the level of formation of the informational worldview of students of the pedagogical university of various fields of education. Perspektivy nauki i obrazovania - Perspectives of Science and Education, 39 (3), 142-160. doi: 10.32744/pse.2019.3.11 
нтенсивное развитие информационного общества в России выдвигает новые требования к современной личности. Внедрение информационных технологий во все сферы жизни и деятельности человека ставит на первый план не только вопрос компетентности в информационной области, но и проблему взглядов, ценностей, отношения человека к информационной деятельности и формируемые этими взглядами действия.

Систему взглядов на информацию, информационную среду, информационную деятельность человека, а также основанные на этих взглядах ценности, идеалы, которые определяют позицию личности по отношению к объектам, явлениям, процессам информационной действительности и регулируют информационную деятельность личности называют информационным мировоззрением [1].

О недостаточном уровне информационного мировоззрения молодого поколения, говорят такие факты, как, участившиеся случаи гибели и травм среди подростков и молодежи из-за желания сделать опасное селфи; уменьшение живого общения в пользу виртуального; рост виртуальных зависимостей среди молодых людей и т.д. Это подтверждается наличием большого количества исследований, отражающих неоднозначное влияние информационного общества на мировоззрение человека.

В данной ситуации важно обратить внимание на уровень сформированности информационного мировоззрения будущего педагога, которое заключается в выработке собственной позиции, адекватного отношения к постоянным и стремительным изменениям информационной среды, а также умении взаимодействовать в глобальном информационном пространстве [2]. Наличие информационного мировоззрения у будущего педагога является основой для развития нравственной, эстетической, правовой культуры современной человека [3].

Следует обратить внимание, что количество дисциплин, отвечающих за информационную подготовку студентов-педагогов постоянно растет. В учебный план включаются курсы, изучающие информационные процессы, информационную безопасность, информационные технологии и т.п., однако, отмечаются различия как в количестве, так и в содержании этих дисциплин в зависимости от направления образования. В связи с такой разницей планов подготовки специалистов очевидно, что уровень информационной компетентности у студентов информатиков значительно выше, нежели у гуманитариев или студентов естественно-научного направления, ведь количество дисциплин, отвечающих за информационную подготовку у них существенно больше, а, следовательно, знания и компетенции в информационной области у них сформированы на совершенно другом уровне. Однако, можно ли утверждать, что насыщение специальными дисциплинами влечет за собой повышение уровня информационного мировоззрения? Исследований такого рода нам не встречалось. Это послужило мотивом изучения данного вопроса.

В связи с озвученными проблемами, целями данного исследования является: определение уровня сформированности информационного мировоззрения студентов старших курсов педагогических вузов; сравнительный анализ информационного мировоззрения студентов трех направлений образования (гуманитарного, естественно-научного и информационно-технического). Под информационно-тех- 
ническим направлением образования будем понимать образование, которое имеет целью подготовку специалистов в области информатики, информационных технологий, технических наук.

\section{Обзор литературы}

В последние годы проблема влияния информационного общества на мировоззрение человека активно изучается. В качестве факторов, отрицательно влияющих на сознание как взрослого, так и молодого человека главными называются средства массовой информации (СМИ) и Интернет.

СМИ сегодня это не только информационный ресурс, в большей степени это уже поставщик развлекательных услуг. Более того, качество развлекательных каналов, сериалов, телешоу далеко не всегда нацелены на культурное развитие своего потребителя и это, безусловно, влияет на мышление, сознание, мировоззрение зрителя. Принято считать СМИ одним из основных инструментов конструирования культуры, воспитания и поведения личности [4], это инструмент влияния, фактор формирования мировоззрения в глобальном масштабе, который на сознательном и бессознательном уровнях управляет жизнью человека, навязывает ему мировоззренческие стандарты [5]. Так, С.А. Левина, изучая проблемы манипулирования массовым сознанием через СМИ пишет: «Противостоять такому тонкому воздействию крайне сложно без специальных знаний» $[6$, с. 68].

Опасность вызывает не только смещение СМИ от информационной функции к развлекательной, важно обратить внимание и на форму подачи информации. Одно и то же событие часто на разных новостных каналах освещается по-разному. Просматривается четкая позиция выгоды преподнесения того или иного материала читателю, зрителю, «... форма, в которой представлена информация, приобретает все большее значение и начинает доминировать в новом медиадискурсе» [7]. СМИ несут информацию, содержание которой уже содержит готовые оценки, убеждения и подается всё таким образом, чтобы привлечь к себе внимание, это касается не только телевидения и периодических изданий, статус СМИ получили многие интернет-ресурсы.

Интернет-пространство является еще одним провокатором духовности в наше время. Ведь помимо наличия большого количества нужной и полезной информации, сеть несет серьезные опасности. Особенно это касается молодого поколения, которое без интернета не обходится ни дня.

Проблемы засорения интернет-пространства ложной и вредоносной информацией, а также целенаправленного ее распространения через социальные сети рассматривают С. А. Дружилов, Р.Р. Ниязова. Авторы подчеркивают, что искажение информации негативно воздействуют на картину мира, мировоззрение и жизненную позицию человека $[8 ; 9]$.

Вывод о недостаточном уровне информационного мировоззрения в молодежной среде делает Л. Д. Забокрицкая, среди проблем современной молодежи автор выделяет интернет-зависимость, разрыв реальных социальных связей и подмена их виртуальными связями, утрата свободы личности, утечка личной информации, вовлечение в преступные и деструктивные группы посредством Интернета и др. [10].

О влиянии киберпространства на мировоззрение молодежи пишут Кудашина В.Л. и Пустоселова К.С., ученые подчеркивают, что «... проблема наиболее остро 
стоит в случае интернет-зависимости подростков, так как негативный эффект только усиливается» [11].

Приведенный обзор исследований позволяет сделать вывод о негативном влиянии информационного общества на мировоззрение молодежи и формирование, развитие данного качества это прежде всего задача образования. Это подтверждают исследования современных ученых, так, приоритетной задачей образования Квашнина Д.А. считает сформирование нового мировоззрения, которое основано на понимании центральной роли информации и информационных процессов как в природных, так и в социальных явлениях [12]. Об изменении парадигмы образования пишет Ямщиков А.А., автор уточняет, что приоритеты должны смениться в сторону усиления компетенций в области информационной культуры и формирования информационного мировоззрения [13]. Однако же согласно исследованиям Гейхман Л.К., Клейман Э.И., Клейман Л.А. [14], на данный момент основное место в образовании занимают вопросы активного вовлечения в образовательный процесс информационных технологий, насыщения образовательных учреждений техникой, использования Интернета, развития дистанционного образования, при этом нравственность молодого поколения остается вне должного внимания. Недостаточность изученности вопроса формирования информационного мировоззрения будущего педагога также рассматривалось автором статьи ранее [15].

Подводя итог обзору литературы можно сделать вывод, что вопрос изучения информационного мировоззрения требует особого внимания. Результаты становления информационного общества влияют на подростков, молодежь и педагог должен уметь влиять на становление нового вида мировоззрения ребенка, а для этого он сам должен обладать достаточно высоким уровнем данного качества личности. Студент, заканчивающий педагогический вуз, в ближайшем будущем окажется в стенах школы и столкнется со всеми описанными выше проблемами, поэтому наличие данного качества у будущего педагога является необходимым. Это подтверждает важность исследования уровня сформированности информационного мировоззрения у студента педагогического вуза на последней стадии обучения.

Отметим, что исследований, освещающих зависимость информационного мировоззрения от количества дисциплин, отвечающих за информационную подготовку студента, а также сравнивающих информационное мировоззрение студентов разных направлений, нам не встречалось.

\section{Материалы и методы}

Для проведения педагогической диагностики был выбран письменный опрос (анкетирование). Под анкетой понимается серия тематически взаимосвязанных вопросов [16].

Для разработки анкеты мы обратились к сути понятия «информационное мировоззрение». Анализ подходов к определению понятия позволил выделить важный существенный признак: информационное мировоззрение включает в себя взгляды, ценности, убеждения, идеалы, принципы познания и поступки людей в ходе информационной деятельности.

Информационная деятельность определяется как деятельность по регистрации, сбору, обработке, хранению, передаче, отражению, транслированию, тиражированию, продуцированию информации об объектах, явлениях, процессах, как реально 
протекающих, так и представленных виртуально, и скоростная передача любых объемов информации, представленной в различной форме, с использованием средств информационных и коммуникационных технологий [17]. Сюда же следует отнести деятельность по защите информации.

Проводя изучение понятия «информационная деятельность», нами были выделены следующие разделы для анкетирования.

Поиск (сбор) информации. Следует обратить внимание на то, какие источники использует человек, обращается ли он к проверенным сайтам, библиотекам. Зачастую, начиная работу по сбору информации, человек вводит ключевые слова в поисковой системе и используют первые открывшиеся ссылки, что, конечно, не является правильным.

Также важны взгляды, отношение и поступки личности по отношению к плагиату: как человек относится к использованию найденной информации, делает ли он ссылки на источники, использует ли систему антиплагиата.

Еще одним свойством, характеризующим информационный процесс сбора информации, можно назвать отношение к использованию информационных технологий при его проведении. Автоматизация таких методов как анкетирование, тестирование позволит существенно облегчить следующий процесс, относящийся к информационной деятельности - обработку информации.

Обработка информации. Важно обратить внимание на отношение личности к использованию нелицензионного программного обеспечения. Если юридические лица, на сегодняшний день, в этом направлении достаточно ограничены, и выявление данного нарушения грозит организации серьезными штрафами, то личное использование программного обеспечения пока не регулируется и не проверяется.

Передача информации. Здесь следует обратить внимание на постоянное развитие технологий. Вопрос уже не стоит об использовании информационных технологий, вопрос стоит о собственном развитии в этой области. Если еще недавно организация видеоконференции, совместное обсуждение темы было достаточно непростым трудоемким процессом, то сейчас каждый человек, имеющий смартфон, может организовать и провести видеоконференцию в мессенджере, устроить обсуждение работы в контакте и т.п. Взгляды на развитие технологий, стремление к изучению нового являются важной мировоззренческой характеристикой данного процесса.

Важно также не увлекаться и, например, иметь свои взгляды на спам (массово рассылаемые сообщения, предназначенные лицам, не выражавшим желания их получать, несмотря на предпринятые меры по предотвращению этой рассылки [18]). Так, пересылка «писем счастья», вряд ли можно назвать характеристикой высокого уровня информационного мировоззрения.

Еще одним мировоззренческим показателем процесса передачи информации можно назвать взгляды на выбор оператора связи или провайдера, они должны обосновываться не только стоимостью услуг, но и качеством передаваемого сигнала, так как именно это в итоге определяет насколько обеспечивается защита от помех в процессе передачи информации через сотовую связь и интернет.

Хранение информации. В этом направлении, например, уже давно стало актуальным изучение и использование облачных сервисов, что позволяет иметь доступ к информации из любой точки мира и не занимать место на жестком диске.

Также вопрос хранения требует от студента взглядов на систематизацию информации, сохранение резервных копий ит.п. 
Защита информации. Изучая информационное мировоззрение в рамках данного процесса, следует рассмотреть взгляды и действия обеспечение информационной безопасности, например, такие как установка на технические устройства антивирусного программного обеспечения, ограничения использования смартфонов для проведения финансовых операций.

Также следует изучить взгляд на хакерство. Ведь, несмотря на то, что хакеры - это очень умные и, как правило, молодые люди, и сейчас огромное количество художественных фильмов, в которых хакеры, взламывающие сети банков, энергетических компаний и др., являются положительными героями. Однако, хакеры такими действиями нарушают закон.

Информачионное пространство личности. Проявление мировоззренческих взглядов в данном направлении можно увидеть в деятельности человека в социальных сетях, видеоблогах, компьютерных играх. При этом, с одной стороны, наличие, например, страницы в социальной сети является на сегодняшний день, показателем жизни «в ногу со временем». С другой стороны, потеря времени в соц. сетях это одна из возникающих проблем и важно соблюдать баланс. Здесь же важно рассмотреть взгляды респондента на опасные селфи, которые все чаще делает молодежь с целью получить популярность в сети.

Анкета была разработана таким образом, чтобы охватить указанные выше темы, включает 40 вопросов, каждый вопрос имеет 3 варианта ответов. Каждый ответ был оценен в 0, 1 или 2 балла. При обработке анкеты, каждый респондент получал итоговое количество баллов (максимально 80). При количестве баллов меньше 40 - уровень сформированности информационного мировоззрения считается низким, от 40 до 60 - средний, выше 60 - высокий.

Для оценки ответов, использовались следующие критерии:

- соответствие взглядов и действий закону РФ;

- направленность взглядов и действий на сохранение здоровья/жизни человека;

- направленность взглядов и действий на поддержание информационной безопасности личности;

- направленность взглядов и действий на поддержание баланса между реальным и виртуальным мирами;

- взгляды и отношение к содержанию информации (умение различать факты и мнения, действия по поиску альтернативных мнений, взглядов).

Для сравнения уровня информационного мировоззрения между направлениями и установления достоверности различий (сходства) использованы методы математической статистики.

Наглядное представление числовых данных исследования возможно с помощью описательной статистики. Описательная статистика используется для компактного описания имеющихся данных и подразумевает описание результатов с помощью различных агрегированных показателей и графиков [19]. По числовым данным, отражающим процент студентов, относящихся к низкому, среднему и высокому уровню сформированности ИМ построены гистограммы.

Оценку различий между тремя группами, позволяет выполнить критерий Крускала-Уоллиса, эмпирическое значение которого было рассчитано с помощью табличного процесcopa Microsoft Excel. Так как количество испытуемых в сравниваемых группах больше пяти, критическое значение берется из таблицы критических значений критерия $\chi^{2}\left(\chi_{0,05}^{2}=5,991\right)$ [20, с. 24]. 
Исследование проводилось в Педагогическом институте ФГБОУ ВО «Иркутский государственный университет». В исследовании приняли участие 111 студентов выпускных курсов трех направлений: гуманитарное, естественно-научное и информационнотехническое. Гуманитарное образование представлено бакалаврами, обучающимися по направлению «Педагогическое образование», профили: «История - Обществознание», «Русский язык - Литература», «Иностранный язык (английский) - Иностранный язык (китайский)». Резидентами естественно-научного образования являются бакалавры, заканчивающие обучение по направлению «Педагогическое образование», профили: «Безопасность жизнедеятельности - География», «Безопасность жизнедеятельности - Химия». Информационно-техническое образование представлено студентами-бакалаврами направлений «Педагогическое образование» (профиль «Физика - Информатика») и «Профессиональное обучение» (профиль «Информатика и вычислительная техника»).

Количество дисциплин, отвечающих за информационную подготовку студентов изучаемых видов образования, отличается и приведен в Таблице 1 (согласно учебному плану). Дисциплинами, отвечающими за информационную подготовку, будем считать такие дисциплины, которые направлены на изучение и использование различных информационных технологий и способствуют формированию информационной компетентности студента.

Таблица 1

Количество дисциплин, отвечающих за информационную подготовку студентов

\begin{tabular}{|c|c|c|}
\hline № & Направление/Профиль & $\begin{array}{c}\text { Количество дисциплин, } \\
\text { отвечающих за } \\
\text { информационную } \\
\text { подготовку }\end{array}$ \\
\hline \multicolumn{3}{|c|}{ Гуманитарное образование } \\
\hline 1 & $\begin{array}{l}\text { Направление «Педагогическое образование», } \\
\text { профиль «История - Обществознание» }\end{array}$ & 2 \\
\hline 2 & $\begin{array}{l}\text { Направление «Педагогическое образование», } \\
\text { профиль «Русский язык - Литература» }\end{array}$ & 2 \\
\hline 3 & $\begin{array}{l}\text { Направление «Педагогическое образование», } \\
\text { профиль «Иностранный язык (английский) - Иностранный язык (китайский)» }\end{array}$ & 5 \\
\hline \multicolumn{3}{|c|}{ Естественно-научное образование } \\
\hline 4 & $\begin{array}{l}\text { Направление «Педагогическое образование», } \\
\text { профиль «Безопасность жизнедеятельности - География» }\end{array}$ & 4 \\
\hline 5 & $\begin{array}{l}\text { Направление «Педагогическое образование», } \\
\text { профиль «Безопасность жизнедеятельности - Химия» }\end{array}$ & 4 \\
\hline \multicolumn{3}{|c|}{ Информационно-техническое образование } \\
\hline 6 & $\begin{array}{l}\text { Направление «Педагогическое образование», } \\
\text { профиль «Физика - Информатика» }\end{array}$ & 25 \\
\hline 7 & $\begin{array}{l}\text { Направление «Профессиональное обучение», } \\
\text { профиль «Информатика и вычислительная техника» }\end{array}$ & 27 \\
\hline
\end{tabular}

Приведем сравнение взглядов студентов разных видов образования, по выделенным разделам анкетирования. 
Поиск (сбор) информации. Ответы респондентов показали примерно одинаковые взгляды на отношение к плагиату и компьютерному тестированию. Так, например, большинство студентов всех направлений образования считают, что научные работы следует, проверять на плагиат, однако предпочитают, чтобы пороговый процент был меньше (59\% - гуманитарное, 71\% - естественно-научное, 58\% - информационно-техническое). На вопрос об отношении к компьютерному тестированию, подавляющее большинство респондентов ответили, что относятся положительно (70\% - гуманитарное, 84\% - естественно-научное, 79\% информационно-техническое образование).

Изучая способы поиска информации, отметим, что большинство студентов чаще всего предпочитают пользоваться поисковыми системами в сети Интернет и, как правило, просматривают не больше первых двух страниц результатов поиска. Интересно, что именно студенты информационно-технического образования, в большей степени ограничиваются просмотром первых двух страниц поиска (см. рис. 1).

пуманитарное घестественно-научное информационно-техническое

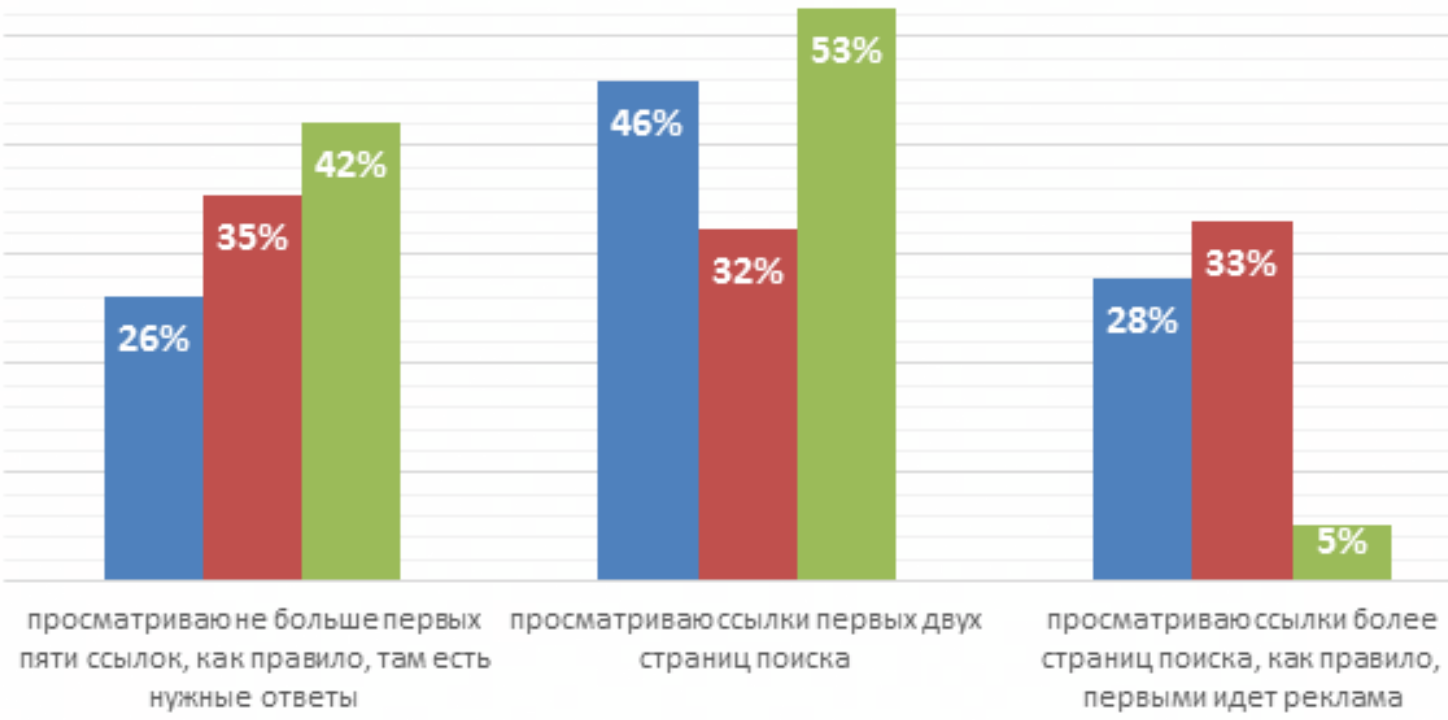

Рисунок 1 Диаграмма соотношения респондентов по количеству просматриваемых ссылок при поиске информации в поисковой системе

Обработка информации. Изучая взгляды, отношение и действия по использованию нелицензионного программного обеспечения (ПО), было отмечено, что лишь незначительная часть студентов относится к данному вопросу крайне отрицательно, большинство студентов относятся к этому нормально и используют пиратское ПО. Результаты по данной группе вопросов между исследуемыми группами примерно одинаковые, студенты информатики используют нелицензионное ПО чуть чаще (см. рис. 2).

Передача информации. Достаточно положительные взгляды на развитие технологий, стремление к изучению нового показали студенты гуманитарного (66\% - относятся нормально, 30\% - крайне положительно) и естественно-научного образования (77\% относятся нормально, 13\% - крайне положительно). Большинство представителей информационно-технического образования относятся к постоянному обновлению техники и ПО крайне положительно (47\% - относятся нормально, 53\% крайне положительно).

Средние показатели у всех респондентов наблюдаются при взглядах на спам, отношение к выбору поставщиков связи. 


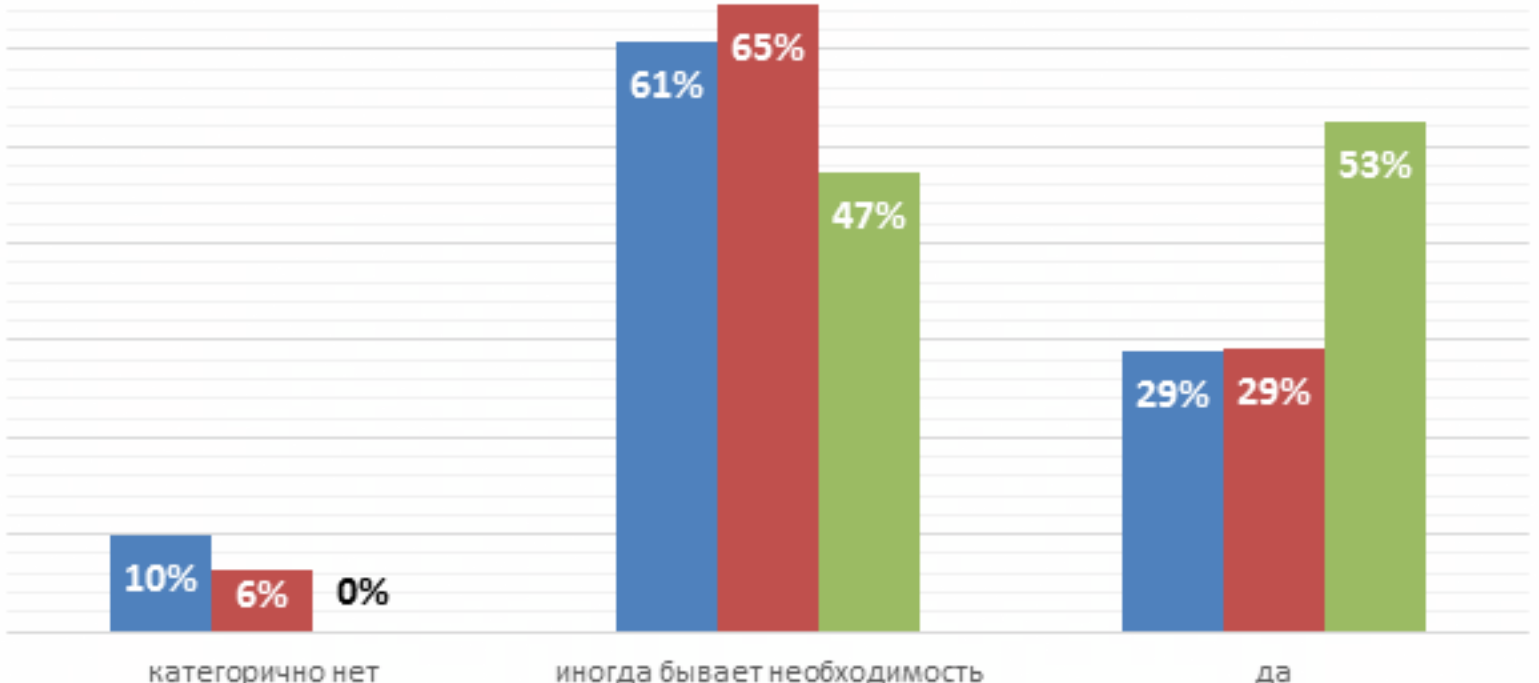

Рисунок 2 Диаграмма соотношения респондентов по использованию нелицензионного ПО

Хранение информации. В вопросе использования для хранения данных облачных сервисов, взгляды у большинства респондентов гуманитарного и естественно-научного направлений совпадают. Чаще всего студенты данных направлений используют облачные диски, когда им это «предлагают» технические средства. Студенты информационно-технического направления более образованы в этом вопросе и их показатели сравнительно выше (см. рис. 3).

гуманитарное ш естественно-научное информационно-техническое

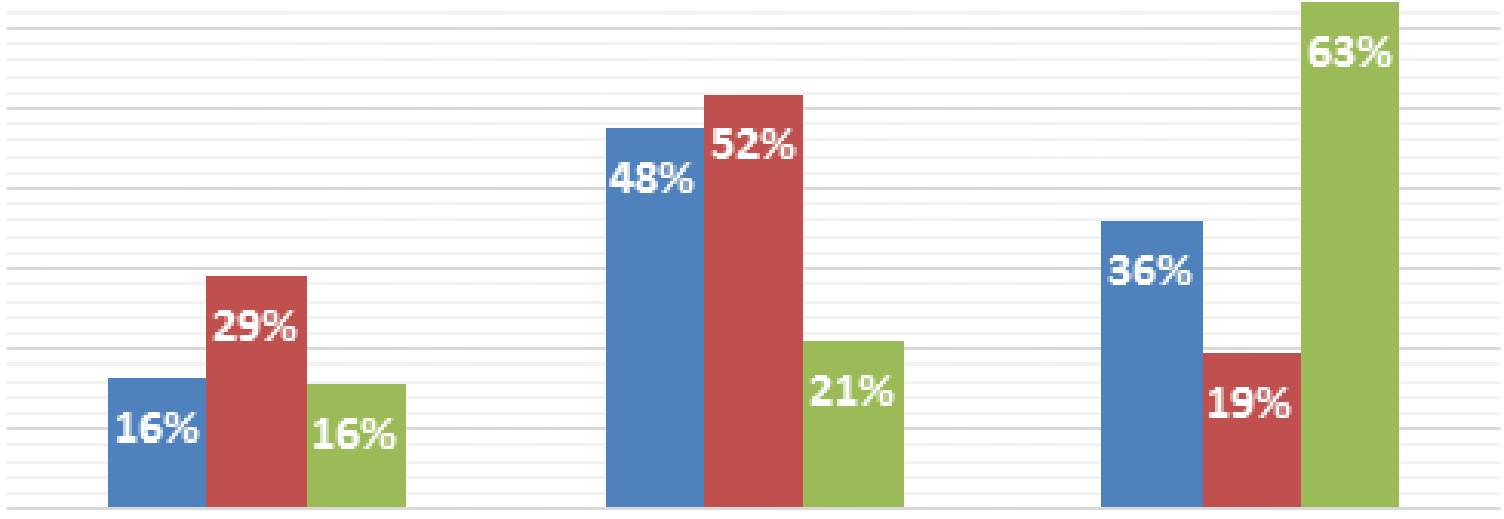

нет, не использую / не знаю

иногда, например, когда как это сделать телефон предлагает сохранить

да, используючасто на облаке

Рисунок 3 Диаграмма соотношения респондентов по использованию для хранения данных облачных сервисов

Взгляды, отношение и действия в вопросах систематизации информации на диске, сохранения резервных копий показали примерно одинаковые и не самые высокие 
результаты. Так лишь 39\% гуманитариев, 35\% студентов естественно-научного и 37\% студентов информационно-технического образования периодически создают копии всех документов. Большинство студентов (51\% - гуманитарное, 55\% - естественно-научное, 63\% - информационно-техническое образование) делают копии лишь очень важных документов. Систематизированной же информацию на своем компьютере могут назвать 41\% студентов гуманитарного, 39\% естественно-научного и 42\% информационно-технического направлений образования.

Защита информации. Изучая взгляды и действия по защите информации, студенты мало задумываются об опасности при использовании смартфонов для проведения финансовых операций (мобильным приложением пользуются 97\% студентов гуманитарного, 94\% - естественно-научного и 89\% информационно-технического направлений), при этом антивирусное ПО установлено примерно у половины респондентов гуманитарного (53\%) и естественно-научного (55\%) направлений. Студенты информационно-технического образования более серьезно относятся к данному вопросу (антивирус установлен у $96 \%$ респондентов).

Изучая взгляды на информационные преступления, интересными оказались следующие факты. Несмотря на то, что в общем к информационным преступлениям отношение в основном отрицательное, при уточнении субъектов, в отношении которых были совершены преступления, взгляды студентов меняются. Особенно это заметно у студентов гуманитарного и естественно-научного образования. Так, например, в анкете были два похожих вопроса: 1. Вы услышали новость, что человек, взломав сервер банка и украв крупную сумму денег со счетов чиновников, остался не пойманным. Ваше отношение к этому? 2. Вы услышали новость, что человек, взломав сервер банка и украв крупную сумму денег со счетов благотворительного фонда, остался не пойманным. Выше отношение к этому?

Результаты ответов приведены на рисунках 4, 5, 6.

\section{Ограблены счета чиновников — Ограблены счета благотворительного фонда}

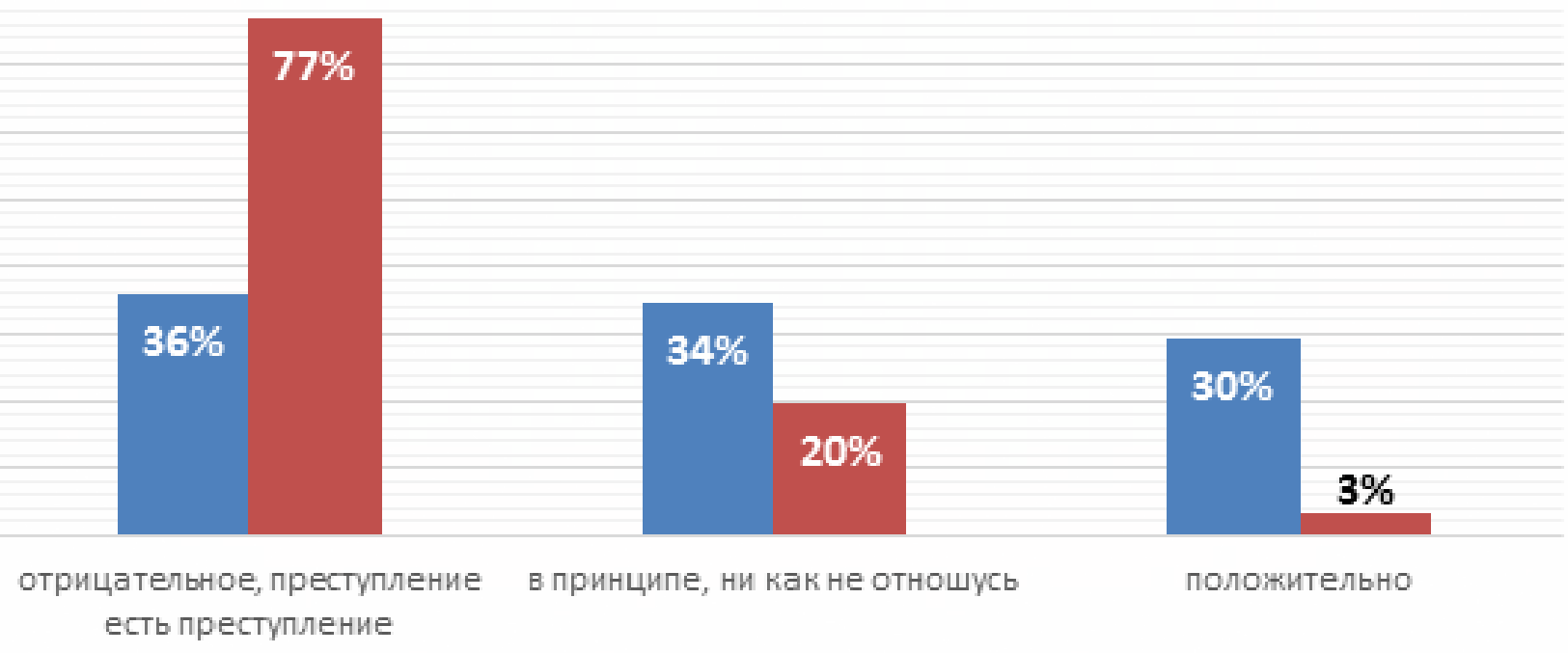

Рисунок 4 Диаграмма результатов отношения студентов гуманитарного направления к информационному преступлению, в зависимости от субъекта преступления 


\section{Ограблены счета чиновников Ш Ограблены счета благотворительного фонда}

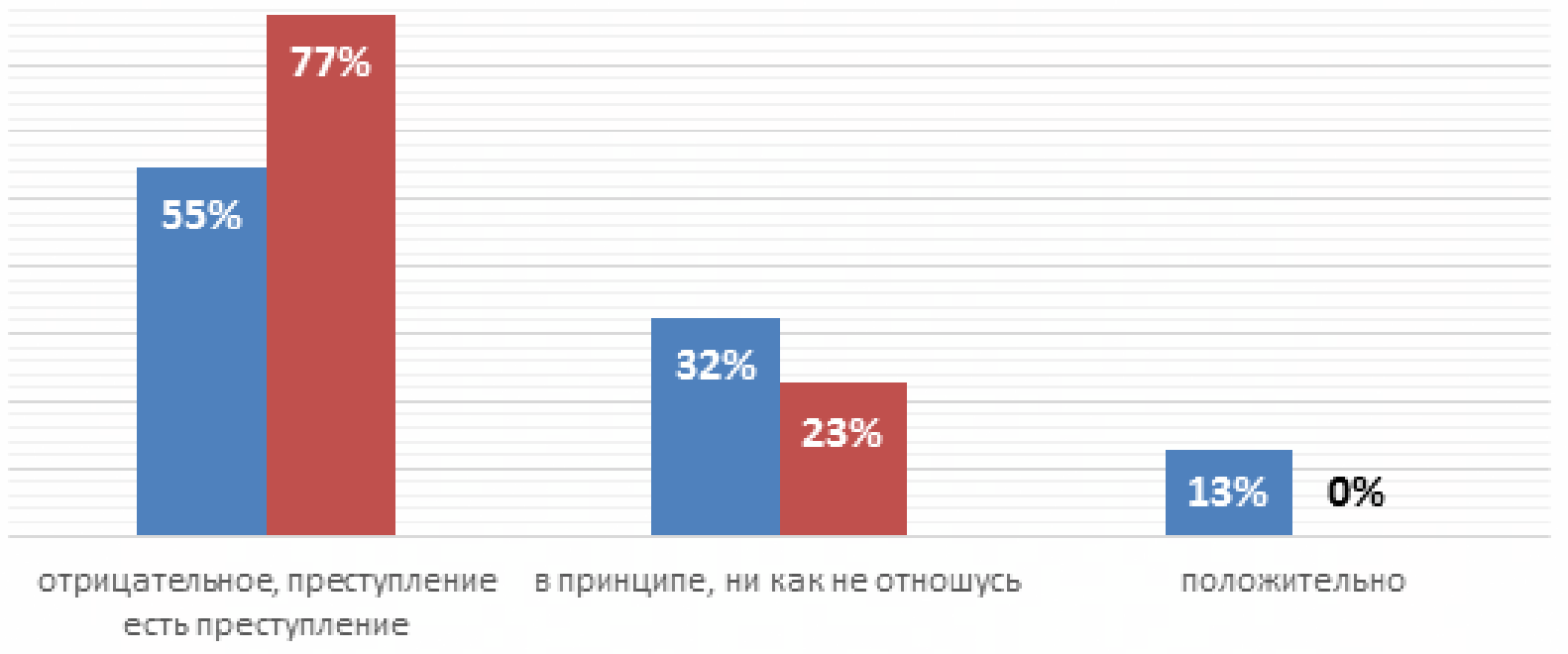

Рисунок 5 Диаграмма результатов отношения студентов естественно-научного направления к информационному преступлению, в зависимости от субъекта преступления

Ограбленысчета чиновников ш Ограбленысчета благотворительного фонда

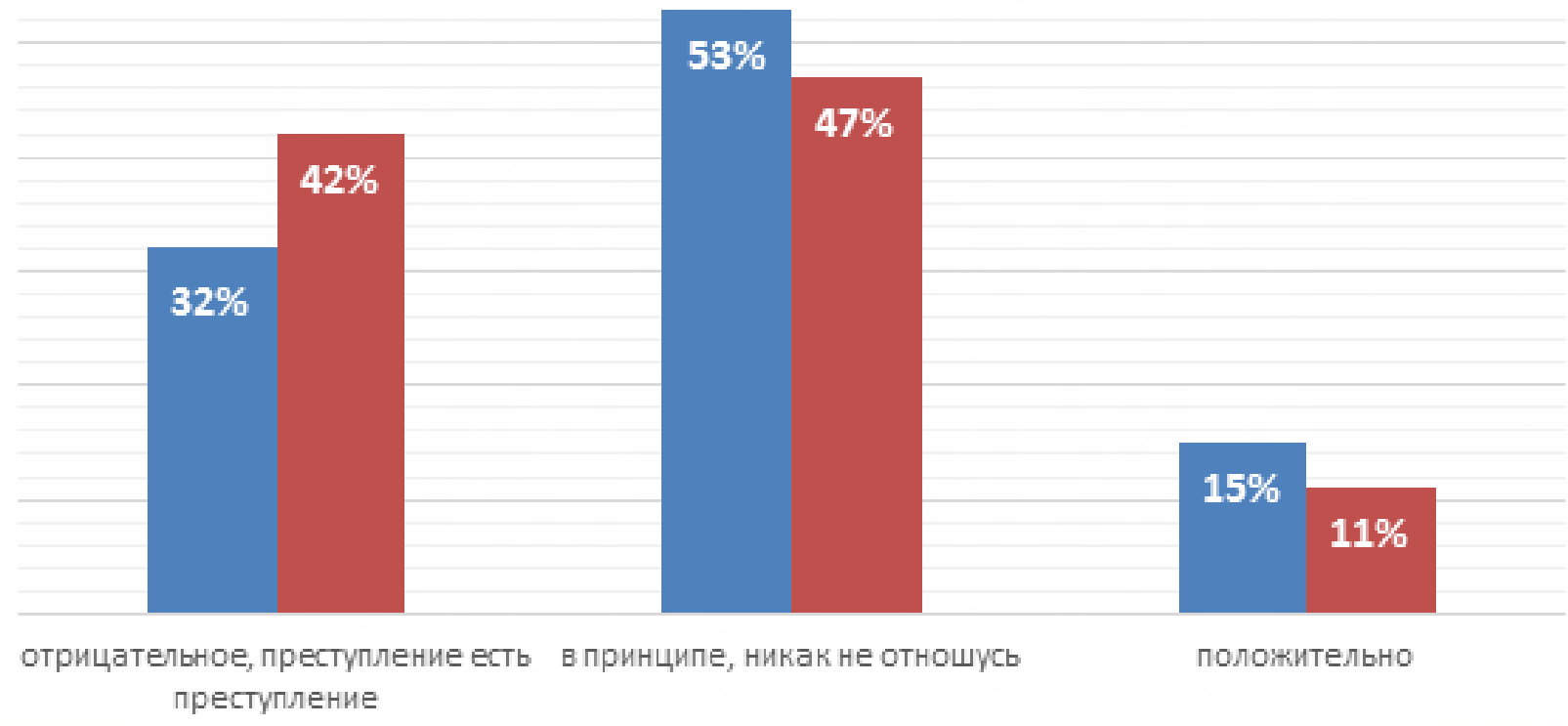

Рисунок 6 Отношение студентов информационно-технического направления к информационному преступлению, в зависимости от субъекта преступления

Информационное пространство личности. Мировоззренческие взгляды на организацию и использование информационного пространства показали разноречивые результаты. Так, например, подавляющее большинство студентов (93\% - гуманитарное, 94\% - естественно-научное, 95\% - информационно-техническое) заходят в сеть интернет чаще чем три раза в день. При этом цель посещения «чаще всего работа/ учеба» выбрали меньше трети студентов (см. рис. 7). 


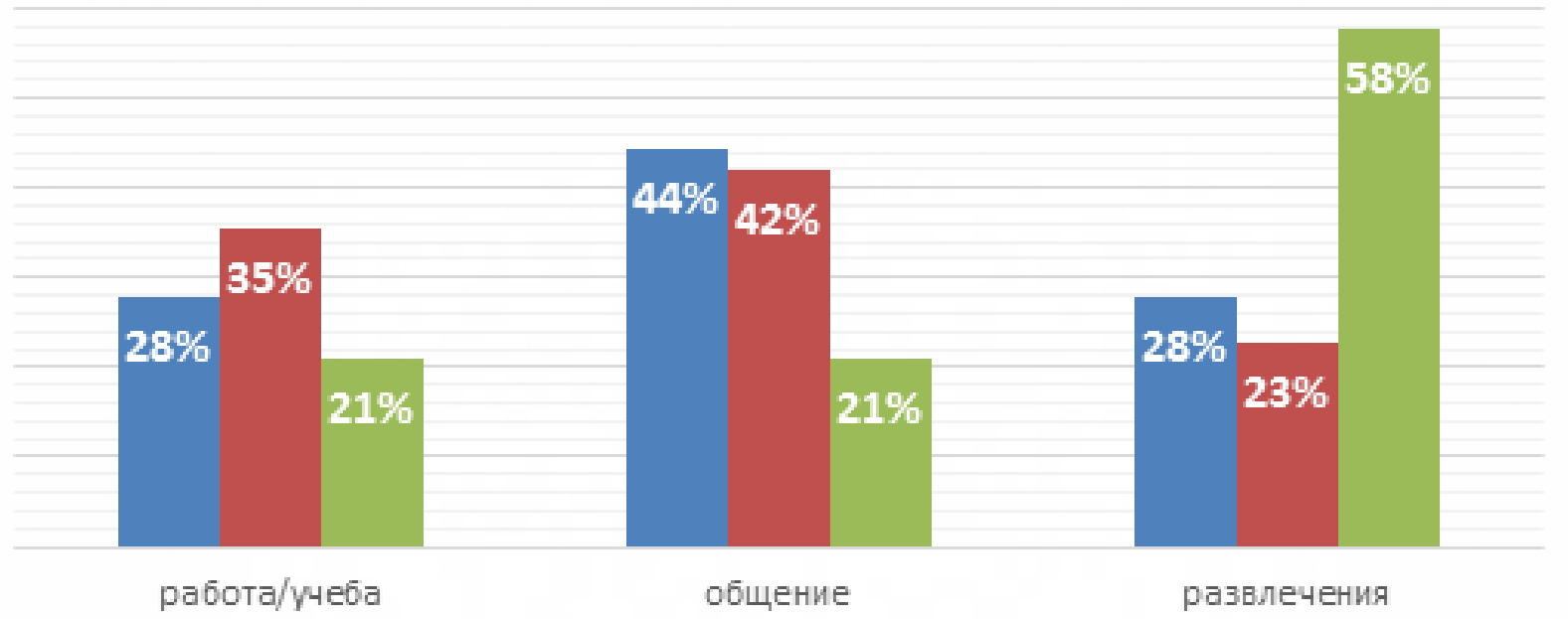

Рисунок 7 Распределение студентов по целям наиболее частого посещения сети Интернет

Следует отметить, что большинство студентов проводит в социальных сетях более часа в день (82\% - гуманитарное, 71\% - естественно-научное, 74\% - информационнотехническое образование), при этом, многие студенты отмечают, что часто не запланировано "теряют время» в соц. сетях. Так, например, на вопрос «Зайдя в соц. сеть, чтобы проверить сообщение (предполагалось не более 10-15 минут) как часто вы остаетесь там дольше?» ответы были следующими (см. рис. 8).

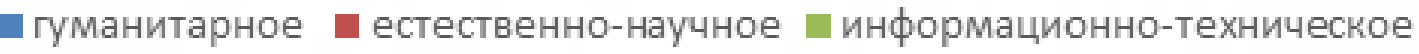

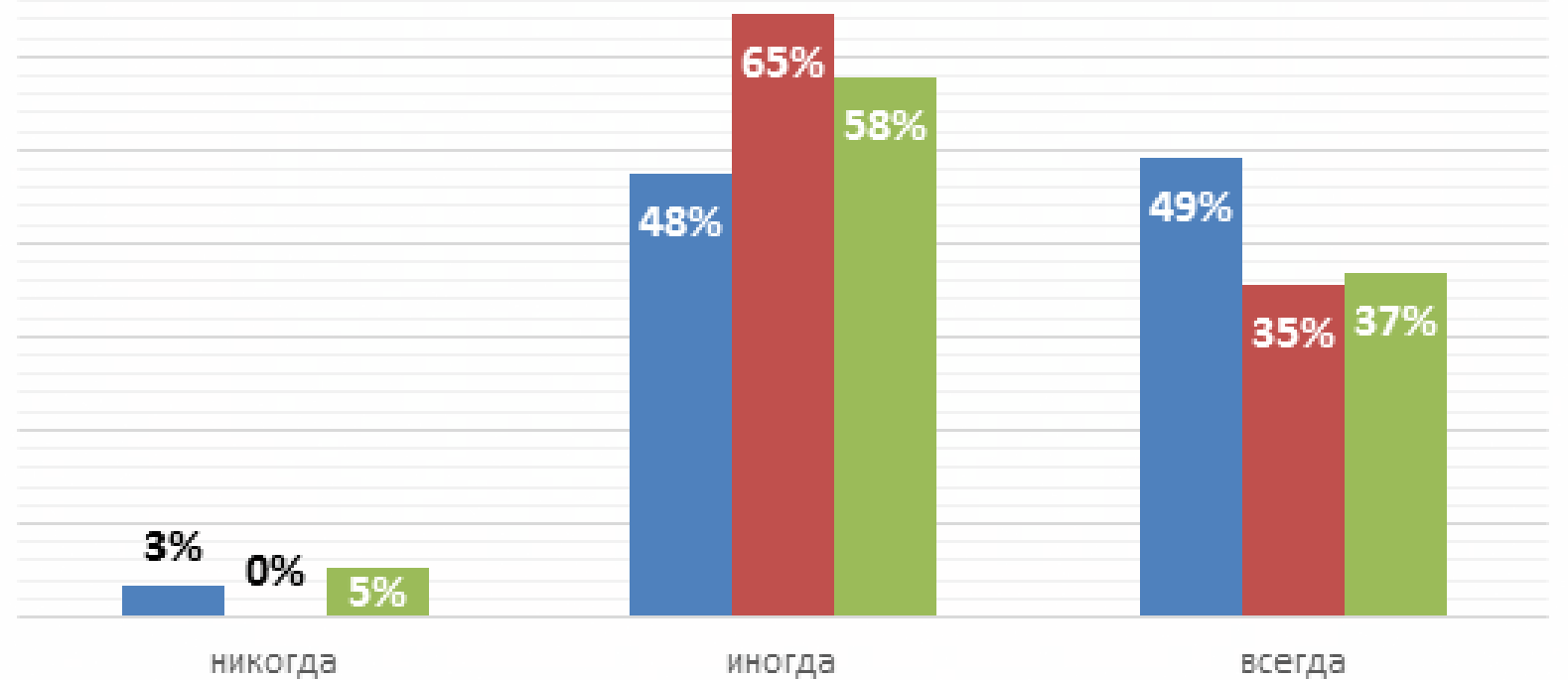

Рисунок 8 Распределение студентов при ответе на вопрос: «Зайдя в соц. сеть, чтобы проверить сообщение (предполагалось не более 10-15 минут) как часто вы остаетесь там дольше?» 
Примерно одинаковые взгляды у студентов всех направлений образования на компьютерные игры. Большинство респондентов гуманитарного и естественно-научного образования не играют (67\% и 55\% соответственно), считают, что иногда можно поиграть, играют несколько раз в неделю 25\% и 35\% соответственно. Немного чаще всего играют студенты информатики (47\% - играют несколько раз в неделю; $16 \%$ играют каждый день).

При ответах на вопросы о предпочтении виртуальной реальности настоящей действительности, значительно больше положительных ответов было у студентов информатиков (21\%) в отличие от гуманитаниев (5\%) и естественников (10\%). При этом виртуальное общение реальному студенты предпочитает практически половина всех респондентов (см. рис. 9).

口уманитарное घестественно-научное घиформационно-техническое

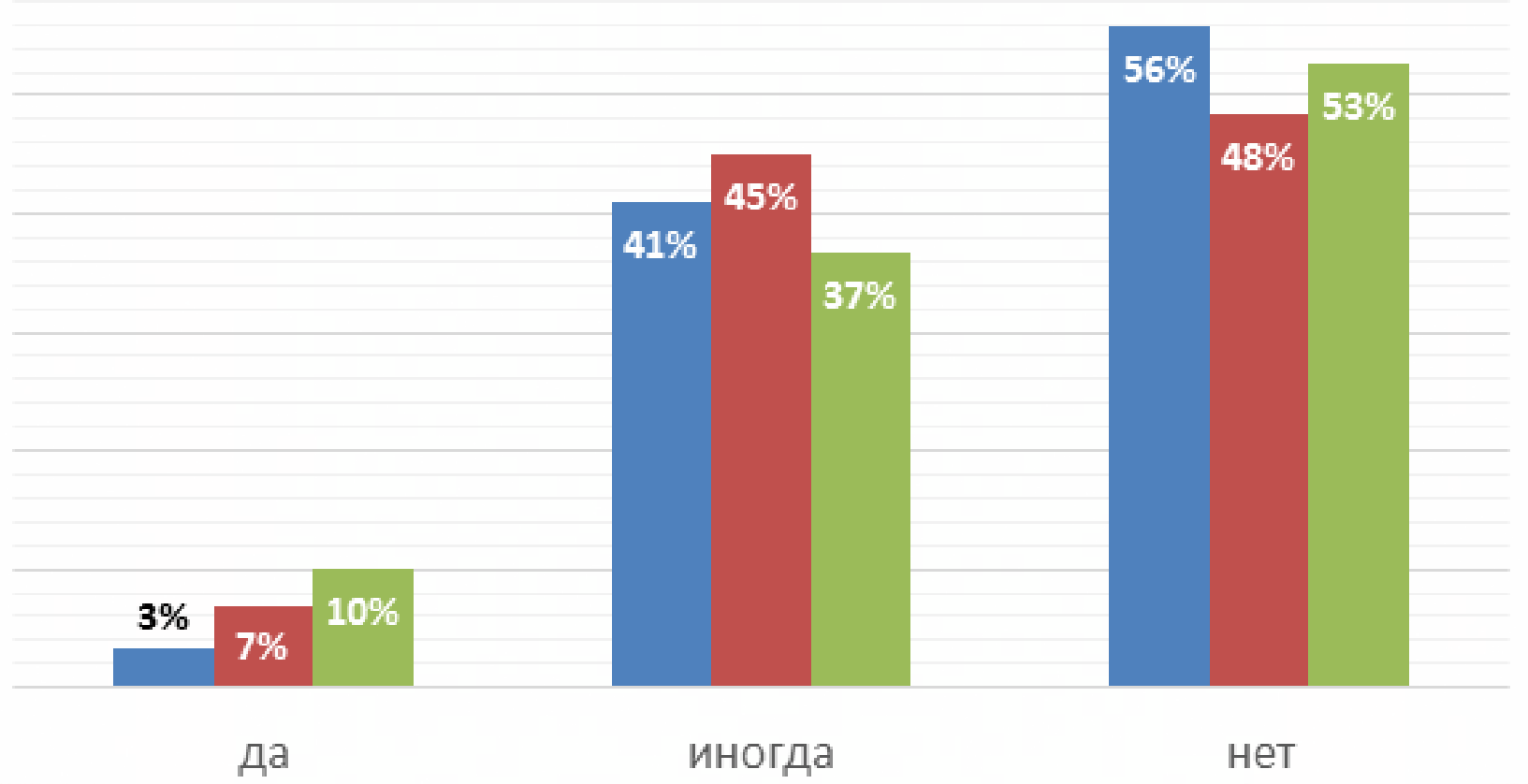

Рисунок 9 Распределение студентов при ответе на вопрос:

«Было ли такое, что вы с другом сидите рядом и переписываетесь по телефону?»

Примерно одинаковые и достаточно высокие взгляды показали студенты всех направлений в отношении к опасным селфи, крайне отрицательно к данному вопросу относятся 69\% - студентов гуманитарного, 68\% - естественно-научного и 63\% информационно-технического образования. При этом некоторые студенты все-таки подвергали свою жизнь опасности ради опасного селфи один или два раза в жизни (16\% - гуманитарное, 16\% - естественно-научное, 5\% - информационно-техническое образование).

В итоге исследования была произведена оценка уровня сформированности информационного мировоззрения студентов всех трех направлений, подавляющее большинство респондентов отнесены к группе с средним уровнем сформированности информационного мировоззрения (85\% - гуманитарное, 90\% - естественно-научное, 79\% - информационно-техническое образование). Результаты представлены на рисунке 10. 


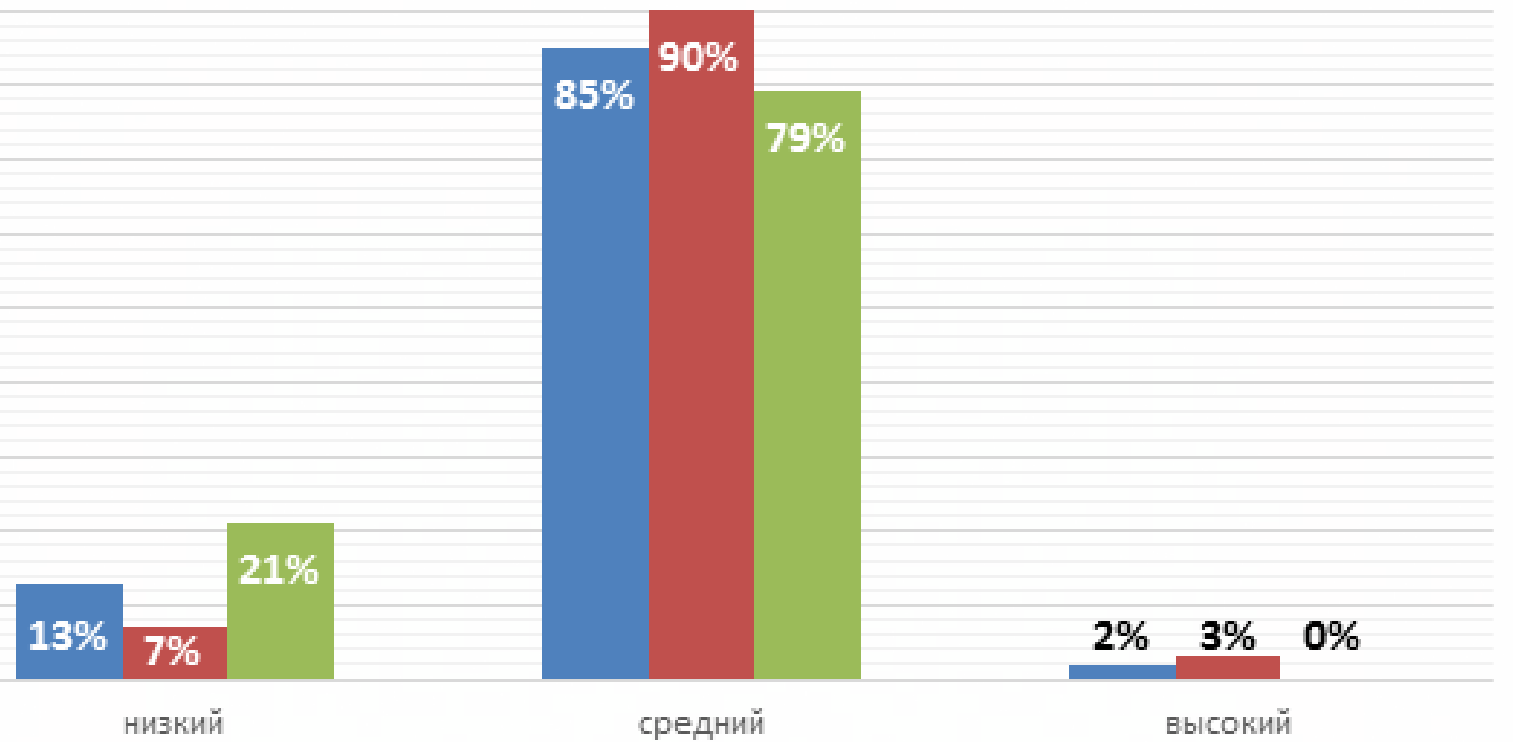

Рисунок 10 Распределение студентов по уровню информационного мировоззрения

Для установления достоверности различия (сходства) исследуемого качества между направлениями образования было рассчитано эмпирическое значение критерия Крускала-Уоллиса: $\mathrm{H}_{\text {эмп }}=0,78$. Сравнивая его с критическим значением получаем $\mathrm{H}_{\text {эмп }}<5,991$, это позволяет сделать вывод, что характеристики сравниваемых выборок совпадают на уровне значимости 0,05.

Таким образом, уровень сформированности информационного мировоззрения студентов старших курсов гуманитарного, естественно-научного и информационнотехнического направлений образования является примерно одинаковым, а количество дисциплин, отвечающих за информационную подготовку и повышающие уровень информационной компетентности не влияет на уровень информационного мировоззрения.

\section{Обсуждение результатов}

В результате исследования, на примере трех направлений образования (гуманитарного, естественно-научного и информационно-технического), доказано, что уровень сформированности информационного мировоззрения студента не зависит от количества дисциплин, отвечающих за его информационную подготовку. Уровень сформированности информационного мировоззрения студентов изучаемых направлений примерно одинаковый (характеристики сравниваемых выборок совпадают на уровне значимости 0,05).

Оценивая непосредственно информационное мировоззрение, следует сказать, что подавляющее большинство студентов всех трех направлений образования имеют средний (85\%), часть студентов низкий (13\%) и лишь 2\% высокий уровень.

Для изменения данной ситуации в положительную сторону можно дать следующие рекомендации. Прежде всего, необходимо чтобы процесс развития информа- 
ционного мировоззрения студента был непрерывным и продолжался на протяжении всего срока обучения.

На младших курсах, как правило, изучаются дисциплины общей подготовки. Анализ учебных планов, позволил выделить ряд из них, имеющих потенциал для развития информационного мировоззрения. Важно, что, изменив формы и содержательную направленность заданий, можно улучшить показатели, не меняя кардинально программы курса. Нужно не просто знакомить студентов с информацией, а заставлять их думать, например, используя такие формы обучения как лекция-дискуссия, лекция с заранее запланированными ошибками, диспут, тренинг.

Так, например, с понятиями «информационная картина мира» и «информационное мировоззрение» студентов можно познакомить в процессе изучения курса «Философия». На дисциплинах, изучающих психологию, возможна организация тренингов для профилактики компьютерной и Интернет зависимостей.

Большой потенциал содержит дисциплина «Информационные технологии в образовании». В программу курса уже включены такие темы как «Информационное общество», «Информационные процессы», «Основы информационной безопасности», «Информационная культура». Однако, как уже доказано, для развития информационного мировоззрения этого мало, помимо знакомства с материалом, возможна, например, организация диспута «Хакеры - за и против!». Также можно при изучении темы «Поиск информации» организовать проблемное занятие, в ходе которого студенты на собственном опыте убедятся, что первые ссылки в результатах поиска не всегда являются полезными. При изучении электронных таблиц одним из заданий можно включить построение диаграммы, демонстрирующей динамику количества подростков, пострадавших во время выполнения опасного селфи и т.п. Целенаправленно выбирая форму проведения занятий, содержание заданий и демонстрационный материал можно способствовать повышению уровня информационного мировоззрения студента.

Развитие информационного мировоззрения на старших курсах мы видим через включение в подготовку студентов специальной дисциплины (возможно курс по выбору), основной целью которой будет является формирование информационного мировоззрения будущего педагога.

В рамках изучения дисциплины должны быть обобщены, систематизированы и углублены знания и умения, сформированные на младших курсах; сформированы знания основ информационной деятельности педагога; сформированы знания и умения по противостоянию влияния СМИ и соц. сетей на сознание человека, ребенка; сформированы знания и умения отбора и анализа информации в интернете, социальных сетях и СМИ (выявления скрытой рекламы, антисемитской информации, сектантской информации и др.); сформированы взгляды на информационные преступления и навыки информационной безопасности; сформированы знания и взгляды на использование информационных ресурсов (создание блогов, видео блогов, опасные селфи и т.д.), информационных образовательных ресурсов. Дисциплина может называться «Информационное мировоззрение будущего педагога».

Таким образом, оказывая целенаправленное и непрерывное влияние на формирование и развитие информационного мировоззрения в течение всего срока обучения, можно способствовать повышению показателей на выходе.

Отсутствие же различий в уровне сформированности информационного мировоззрения у студентов различных направлений подтверждает, что целенаправленное воздействие на развитие данного качества требуется на всех направлениях подготовки. 
Информационное мировоззрение личности является важным показателем для современного человека, развивая и повышая уровень информационной компетентности будущего педагога, нельзя забывать о том, какими взглядами будут руководствоваться студенты при использовании своих знаний. Уровень сформированности информационного мировоззрения выпускника педагогического вуза будет важным показателем его умения способствовать развитию данного качества у своих учеников.

Результаты, полученные в ходе исследования позволяют сделать вывод, что для формирования и развития информационного мировоззрения недостаточно вводить дисциплины, отвечающие за информационную подготовку студентов. Кроме того, число студентов, имеющих высокий уровень составляет лишь $2 \%$ от общего количества.

Вышесказанное говорит о необходимости целенаправленного влияния на формирование информационного мировоззрения студентов педвуза.

В статье достигнута поставленная цель, в дальнейшем планируется изучение способов формирования и развития информационного мировоззрения студентов педвуза.

Благодарности

Автор выражает благодарность сотрудникам деканатов отделений ГЭО и ФМЕНИТО Педагогического института ФГБОУ ВО ИГУ Крутиковой Н.С., Грищенко И.А., Серебренникову И.П., Сергеевой О.А. за помощь в организации анкетирования. А также студентов старших курсов данных отделений за отклик и участие в исследовании. Благодарим рецензентов за положительную оценку статьи, а также научного редактора за ценные рекомендации и помощь в оформлении мыслей автора.

\section{ЛИТЕРАТУРА}

1. Гнатышина Е.В. Мировоззренческие аспекты информационной подготовки педагога профессионального обучения // Инновационные процессы в образовании: стратегия, теория и практика развития: Материалы VI Всероссийской научно-практической конференции. Екатеринбург: Российский государственный профессионально-педагогический университет, 2013. С. 35-37.

2. Дири М.И. Информационная культура современного педагога как условие формирования готовности к применению инновационных технологий // Вестник Самарского государственного технического университета. Серия: Психолого-педагогические науки. 2018. № 1 (37). С. 41-50.

3. Гнатышина Е.В. Некоторые аспекты формирования цифровой культуры будущего педагога в условиях внедрения инновационных образовательных технологий // Современное образование: опыт прошлого взгляд в будущее: Материалы Международной научно-практической конференции. Челябинск, 2018. С. 145147.

4. Klyuev Yu.V. A model of professional communication oriented to humanism in today's social and cultural transformations // Наука и Мир. 2016. Т. 1. № 10 (38). С. 74-77.

5. Зайцева Н.В. Мировоззрение человека в трансформирующемся обществе: философско-культурологический анализ: автореф. дис. ... канд. философ. наук. Белгород, 2016. 21 с.

6. Левина С.А. Технологии управления массовым сознанием // Научные труды Северо-Западного института управления. 2016. Т. 7. № 3 (25). С. 62-68.

7. Guslyakova A.V. Introducing a model of information integration in the present-day mass media // Наука $и$ технологии. 2016. № 2. С. 166-181.

8. Дружилов С.А. Негативные воздействия современной информационной среды на человека: психологические аспекты // Психологические исследования: электронный научный журнал. 2018. Т. 11. № 59. С. 11. 
9. Ниязова Р.Р. Влияние Интернет-ресурсов на мировоззрение молодежи // Северный морской путь, водные и сухопутные транспортные коридоры как основа развития Сибири и Арктики в XXI веке. Сборник тезисов докладов участников Международного конкурса научных работ XX Международной научно-практической конференции. Тюмень, 2018. С. 281-287.

10. Забокрицкая Л.Д. Информационная культура современной молодежи: угрозы и вызовы виртуального социального пространства // Вестник Пермского национального исследовательского политехнического университета. Социально-экономические науки. 2017. № 4. С. 114-123.

11. Kudashina V.L., Pustoselova K.S. Influence of cyberspace on the worldview formation of adolescents // Слово. Предложение. Текст: анализ языковой культуры. 2017. № 13. С. 5.

12. Квашнина Дарья Александровна Информационное общество как феномен и тенденции его развития // Манускрипт. 2016. №12-1 (74). С. 100-102.

13. Ямщиков А.А. Аксиологическая направленность ИКТ в структуре преподавания информатики в колледже // Проблемы современного педагогического образования. 2018. № 61-2. С. 273-276.

14. Гейхман Л.К., Клейман Э.И., Клейман Л.А. Пути решения современных проблем одразования и воспитания личности в процессе становления информационного общества // Вестник Пермского национального исследовательского политехнического университета. Проблемы языкознания и педагогики. 2018. № 1. С. 119-127.

15. Комарова А.А. Формирование информационного мировоззрения будущего педагога: степень изученности проблемы в современных исследованиях // Интернет-журнал «Мир науки», 2018 № 6. URL: https://mirnauki.com/PDF/40PDMN618.pdf (дата обращения: 1.0.2019)

16. Дудина М. М. Основы психолого-педагогической диагностики: учебное пособие. Екатеринбург: Изд-во Рос. гос. проф.-пед. ун-та, 2016. 190 с.

17. Толковый словарь терминов понятийного аппарата информатизации образования. М.: ИИО РАО, 2009.96 с.

18. Cormack G. V. Email spam filtering: A systematic review // Foundations and Trends in Information Retrieval. 2008. Vol. 1. № 4. P. 335-455.

19. Новиков Д.А. Статистические методы в педагогических исследованиях (типовые случаи). М.: МЗ-Пресс, 2004. $67 \mathrm{c}$.

20. Середенко П.В. Методы математической статистики в психолого-педагогических исследованиях: учеб. пособ. 2-е изд., испр. и доп. Южно-Сахалинск: СахГУ, 2009. 52 с.

\section{REFERENCES}

1. Gnatyshina E.V. Worldview aspects of information training of vocational education // Innovative processes in education: strategy, theory and development practice: Materials of the VIth All-Russian Scientific and Practical Conference. Ekaterinburg, Russian State Vocational Pedagogical University Publ., 2013. P. 35-37. (in Russ.)

2. Diri M.I. Modern educator's information culture as readiness formation factor to application of innovative technologies. Bulletin of the Samara State Technical University. Series: Psychological and Pedagogical Sciences. 2018. No. 1 (37). P. 41-50. (in Russ.)

3. Gnatyshina E.V. Some aspects of formation of digital culture of a future teacher in the context of innovative educational technologies implementation. Modern education: the experience of the past - a look into the future: Materials of the International Scientific and Practical Conference. Chelyabinsk, 2018. pp. 145-147. (in Russ.)

4. Klyuev Yu.V. A model of professional communication oriented to humanism in today's social and cultural transformations. Science and World. 2016. Vol. 1. No. 10 (38). P. 74-77. (in Russ.)

5. Zaitseva N.V. Human worldview in the transforming society: philosophical and cultural analysis: Abstract Diss. PhD Philosoph. Sci., Belgorod, 2016. 21 p. (in Russ.)

6. Levina S.A. The technology of mass consciousness management. Scientific works of the North-West Institute of Management. 2016. Vol. 7. No. 3 (25). P. 62-68. (in Russ.)

7. Guslyakova A.V. Introducing a model of information integration in the present-day mass media. Science and Technology. 2016. No. 2. P. 166-181.

8. Druzhilov S.A. The negative impact of the modern information environment: the psychological aspects. Psychological studies: electronic scientific journal. 2018. Vol. 11. No. 59. P. 11. (in Russ.)

9. Niyazov R. R. The impact of Internet resources on the worldview of young people // The Northern sea route, water and land transport corridors as a basis for the development of Siberia and the Arctic in the XXI century. Collection of abstracts of participants of the International competition of scientific works of the XX International scientificpractical conference. Tyumen, 2018. P. 281-287. (in Russ.)

10. Zabokritskaya L.D. Information culture of modern youth: threats and challenges of virtual social space. Bulletin of the Perm National Research Polytechnic University. Socio-economic sciences. 2017. No. 4. P. 114-123. (in Russ.)

11. Kudashina V.L., Pustoselova K.S. Influence of cyberspace on the worldview formation of adolescents. Word. Sentence. Text: analysis of language culture. 2017. No. 13. P. 5.

12. Kvashnina Daria Alexandrovna Information Society as a phenomenon and trends in its development. Manuscript. 
2016. No. 12-1 (74). P. 100-102. (in Russ.)

13. Yamshchikov A.A. Axiological orientation of ICT in the structure of teaching of computer science in college. Problems of modern pedagogical education. 2018. No. 61-2. P. 273-276. (in Russ.)

14. Geykhman L.K., Kleiman E.I., Kleiman L.A. Education and personality upbringing in the process of the information society formation: approaches to solving contemporary problems. Bulletin of the Perm National Research Polytechnic University. Problems of linguistics and pedagogy. 2018. No. 1. P. 119-127. (in Russ.)

15. Komarova A.A. Formation future teacher's in formation world view knowledge of issue in modern researches. World of Science. 2018. No. 6. Available at: https://mir-nauki.com/PDF/40PDMN618.pdf (accessed 1.06.2019)

16. Dudina M.M. Fundamentals of psychological and pedagogical diagnostics: textbook. Ekaterinburg, RSPPU Publ., 2016. 190 p. (in Russ.)

17. Explanatory dictionary of terms of the conceptual apparatus of education informatization. Moscow, RAE Publ., 2009. 96 p. (in Russ.)

18. Cormack G. V. Email spam filtering: A systematic review. Foundations and Trends in Information Retrieval. 2008. Vol. 1. No. 4. P. 335-455. (in Russ.)

19. Novikov D.A. Statistical methods in pedagogical research (typical cases). Moscow, MZ-Press Publ., 2004.67 p.

20. Seredenko P.V. Methods of mathematical statistics in psychological and pedagogical research: studies. benefit $2 \mathrm{nd}$ ed., Rev. and add. Yuzhno-Sakhalinsk, SakhSU Publ., 2009. 52 p.

\section{Информация об авторе \\ Комарова Анна Александровна \\ (Россия, г. Иркутск)}

Доцент, кандидат педагогических наук, доцент кафедры информатики и методики обучения информатике

Педагогический институт

ФГБОУ ВО «Иркутский государственный университет»

E-mail: prokopjeva@rambler.ru

\section{Information about the author}

Anna A. Komarova

(Russia, Irkutsk)

Associate Professor, PhD in Pedagogical Sciences, Associate Professor of the Department of Informatics and Methods of Informatics Teaching Pedagogical Institute

Irkutsk State University

E-mail: prokopjeva@rambler.ru 